\title{
Imaging characteristics of nontuberculous mycobacterial pulmonary nodules
}

\author{
KENGO NISHINO $^{1}$, KESATO IGUCHI ${ }^{2}$, OSAMU ISHIBASHI ${ }^{2}$, YUIKA SASATANI ${ }^{1}$, GEN OHARA ${ }^{1}$, KATSUNORI \\ KAGOHASHI $^{1}$, HIROAKI SATOH ${ }^{1}$
}

\author{
${ }^{1}$ Division of Respiratory Medicine, Mito Medical Center, University of Tsukuba-Mito Kyodo General Hospital, \\ Miya-machi 3-2-7, Mito-city, Ibaraki, 310-0015, Japan \\ ${ }^{2}$ Division of Thoracic Surgery, Mito Medical Center, University of Tsukuba-Mito Kyodo General Hospital, \\ Miya-machi 3-2-7, Mito-city, Ibaraki, 310-0015, Japan
}

\begin{abstract}
Introduction. Nontuberculous mycobacteriosis (NTM) of the lungs can develop nodules. In order to clarify some of the characteristics of lung NTM nodules, we examined volume doubling time (VDT) and maximum standardized uptake value (SUVmax) in positron emission tomography (PET) of pathologically diagnosed NTM nodules.

Methods. From November 2012 to August 2018, clinical and radiological information were retrospectively investigated in eight patients who were surgically resected and diagnosed as NTM. These eight patients were followed up until November 2020 and were confirmed to have no appearance of lung cancer or reappearance of lung NTM nodules. The VDT was calculated using the Schwartz formula.

Results. The median maximum diameter of the nodule at the time of the first CT scan was 16.0 (range: 9.9-20.0) $\mathrm{mm}$. The median maximum diameter of the nodule on CT performed before the surgical biopsy was 18.8 (range: 10.4-32.8) $\mathrm{mm}$. The median doubling time calculated from these results was 203 (range: 20-568) days. Caseous granulomas and acid-fast bacilli were histologically confirmed in all eight patients. Culture of excised nodules revealed Mycobacterium intracellulare in five patients and Mycobacterium avium in three patients. Six patients received PET, and median SUVmax was: 7.0 (range: 3.3-21.0). Median VDT was around 200 days. Some patients had irregular-shaped nodules.

Conclusions. CT/PET-CT characteristics of lung nodules are not reliable in differentiating lung NTM nodules from malignant ones. To avoid unnecessary resection, it may be better to collect various information on imaging findings in the nodule itself and in opacities other than the nodule.
\end{abstract}

Key words: lung mycobacterium infections nontuberculous; X-Ray computed tomography.

\section{What is new? What is important?}

Nontuberculous mycobacteriosis of the lungs can develop nodules. The median doubling time of the nodules was 203 days. Some of them had high maximum standardized uptake value in positron emission tomography. To avoid unnecessary resection, it may be better to collect various information on imaging findings in the nodule itself and in opacities other than the nodule.

\section{INTRODUCTION}

The commonly observed CT findings in patients with lung nontuberculous mycobacteriosis (NTM) are centrilobular, peribronchovascular multiple small nodules, bronchiectasis, consoledation, tree-in-bud in the middle lobe and/or lingual lobe [1-4]. Although not common, in some patients lung NTM manifests as a solitary nodule, mass, or mass-like consolidation mimicking malignancy [5-13]. These lung NTM nodules might be accompanied by these commonly observed parenchymal findings. In order to complicate this aspect, patients with coexisting lung NTM and lung cancer have also been reported [9-13]. It might be particularly difficult to distinguish NTM nodule from lung cancer in patients with NTM nodule without these lung parenchymal findings. The usefulness of FDGPET/CT has been investigated for the purpose of differentiating pulmonary NTM nodules from lung cancer. However, it is known that some patients of NTM nodules have FDG uptake [5, 14, 15].

In order to clarify some of the characteristics of lung NTM nodule, we examined volume doubling time (VDT) and maximum standardized uptake value (SUVmax) in positron 
emission tomography (PET) of patients whose pathological diagnosis was confirmed by surgical biopsy.

\section{MATERIAL AND METHODS}

From November 2012 to August 2018, clinical information and chest CT and FDG-PET images were retrospectively investigated in all the 8 patients with NTM nodule who were surgically resected for the purpose of differentiating lung cancer. These 8 patients were followed up until November 2020 and were confirmed to have no appearance of lung cancer or reappearance of lung NTM nodules. We used multi-slice CT scan: Canon Aquilion Prime SP $(0.5 \mathrm{~mm} \times 80$ PUREViSION (160 slices)(CANON, Tokyo, Japan), and PET-CT: SIEMENS PET-CT (Biograph Horizon, Siemens Healthcare, Tokyo, Japan).

VDT was calculated using the Schwartz formula [19]. The maximum diameter of the nodule on the CT image was measured by pulmonologists. For lung lesions other than nodules, pulmonologists investigated the presence of opacities in the same lobe as nodule existed, and middle lobe, and lingular lobe. The actual calculation method was as follows: VDT was calculated using the chest CT scans that were recorded several times during the clinical course. The VDT was calculated using a modification of the following Schwartz formula of exponential growth (Nakamura): $\quad \mathrm{VDT}=(\mathrm{t} x \log 2) /(3 \times \log$ (V2/V1)); where $\mathrm{V} 1$ and $\mathrm{V} 2$ were the largest diameters on the $\mathrm{CT}$ scan measured at 2 different times, and $\mathrm{t}$ was the time interval between 2 measurements.
This study conformed to the Ethical Guidelines for Clinical Studies issued by the Ministry of Health, Labor and Welfare of Japan. Written comprehensive consent for a noninterventional retrospective study was obtained from each patient. Analysis of the medical records of lung cancer patients was approved by the Ethics Committee in our institute (NO-16-66).

\section{RESULTS}

Table 1 shows the patient backgrounds of the eight patients investigated. The median age was 76 (55-79) years. There were 5 males and 3 females. No patients had diabetes, HIV infection. No patient had corticosteroid treatment. One had a history of smoking, but none had a history of inhalation of industrial substances. No patient had a history of pneumonia, including in childhood.

Nodules were found in 6 cases of the right lung and in 2 cases of the left lung. In 4 patients, the nodule was found in the upper lobe, 3 were in the lower lobe, and 1 was in the middle lobe.

The characteristics of the nodules are shown in Table 2. The median interval between the first CT scan and CT scan taken at prior to surgical biopsy was 133 (range 15-983) days. The median maximum diameter of the nodule at the time of the first CT scan was 16.0 (range: 9.0-20.0) $\mathrm{mm}$. The median maximum diameter of the nodule on CT performed before the surgical biopsy was 18.8 (range: 10.4 32.8) $\mathrm{mm}$. The median VDT calculated from these results was 203 (range: 20-568) days. FDG-PET was performed in 6 of the 8 cases. The median SUVmax of those patients was 7.0 (range: 3.3-21.0).

Table 1

Characteristics of 8 patients with lung NTM nodule

\begin{tabular}{cllll}
\hline No. of patient age, gender & Lesion site & Lesion shape & Opacities in the same robe \\
\hline 1 & 55, male & right upper lobe & Serrated nodule & Emphysematous cyst, scars \\
2 & 63 , male & left upper lobe & Irregular nodule & Scattered, linear opacities \\
3 & 68, female & right upper lobe & Irregular nodule & Scattered, linear opacities \\
4 & 78, male & right lower lobe & Oval & Scattered, linear opacities \\
5 & 76, female & right lower lobe & Irregular nodule & Scattered, linear opacities \\
6 & 79, female & right upper lobe & Irregular nodule & None \\
7 & 78, male & left lower lobe & Oval & Scattered, linear opacities \\
8 & 75, male & right middle lobe & Elliptical nodule & Linear opacities \\
\hline
\end{tabular}


Table 2

Doubling time and PET SUVmax in 8 patients with lung NTM nodule

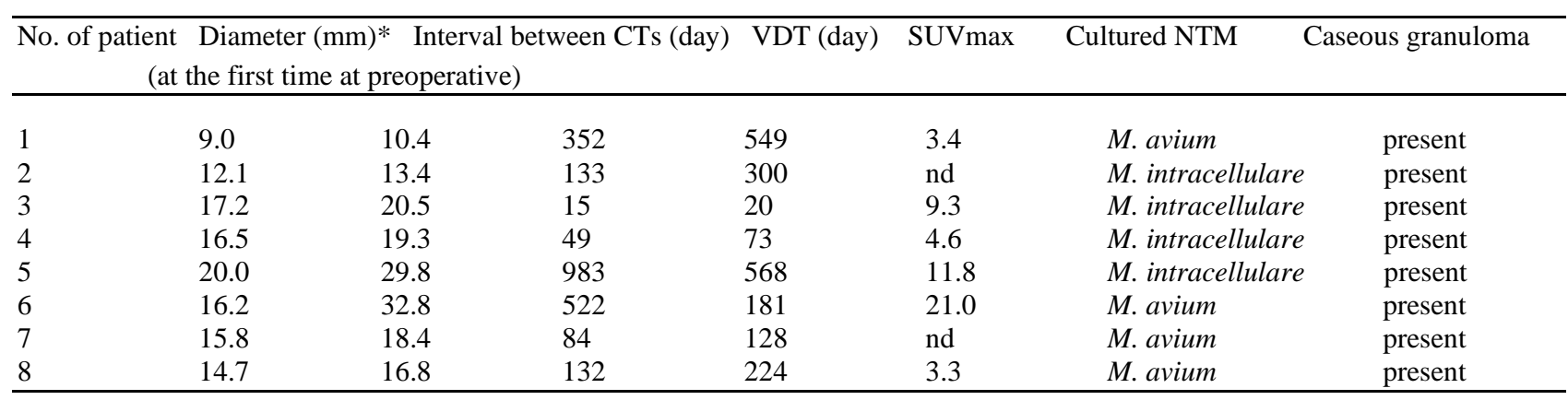

PET: positron emission tomography, SUVmax: maximum standardized uptake value, NTM: non-tuberculous Mycobacterium, nd: not done

In 7 patients, scattered nodular and linear opacities were confirmed in the same lung lobe and in the middle lobe/lingular lobe. Changes in shape of NTM nodules were seen in 3 patients: 1 from an oblong elliptical nodule to a circular nodule, 1 from an oblong irregular nodule to a longitudinal irregular nodule, and 1 case from a longitudinal irregular nodule to a horizontal irregular nodule. Caseous granulomas and acidfast bacilli were histologically confirmed in all 8 patients. Culture of excised nodules revealed Mycobacterium intracellulare in 5 patients and Mycobacterium avium in 3 patients.

We present nodules in two patients (Figure 1: patient number 3 and Figure 2: patient number 6 in Table 1). The nodule in case 3 was nearly spherical and the nodules in case 6 were irregular. Both nodules had irregular margins, but there were no findings of entrainment in the surrounding structure.

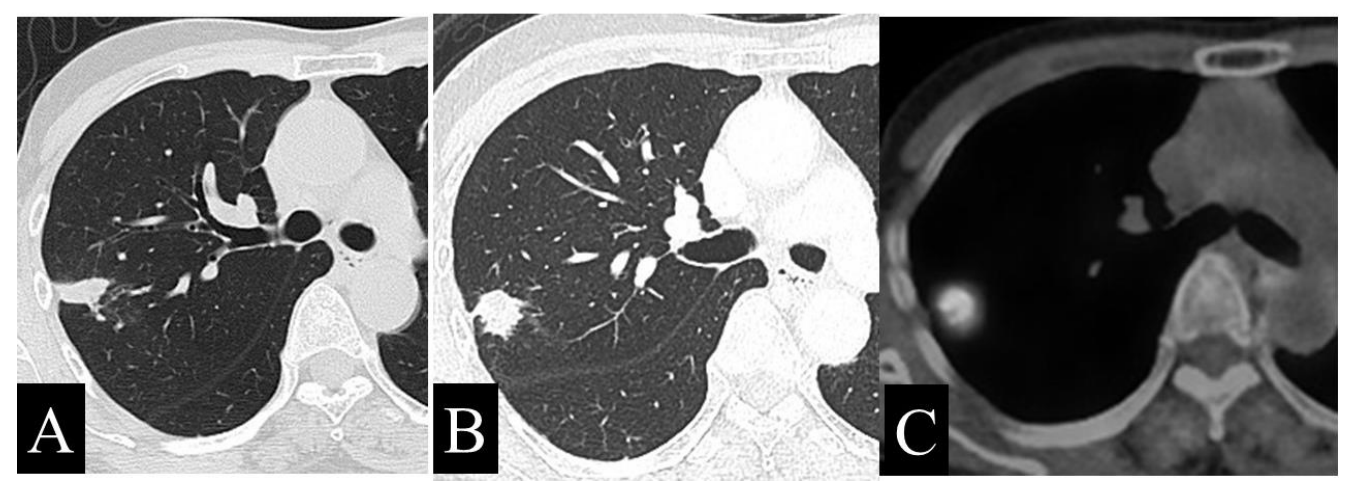

Figure 1. Chest CT and FDG-PET/CT of lung NTM nodule in a patient (Patient number 3 in Table 1). A: a maximum diameter $17.23 \mathrm{~mm}$ nodule in the upper right lobe taken on the first chest CT scan, B: the same nodule increased up to $20.46 \mathrm{~mm}$ taken at prior to surgical biopsy, C: FDG-PET/CT scan showing the SUV max of the nodule was 9.33 .

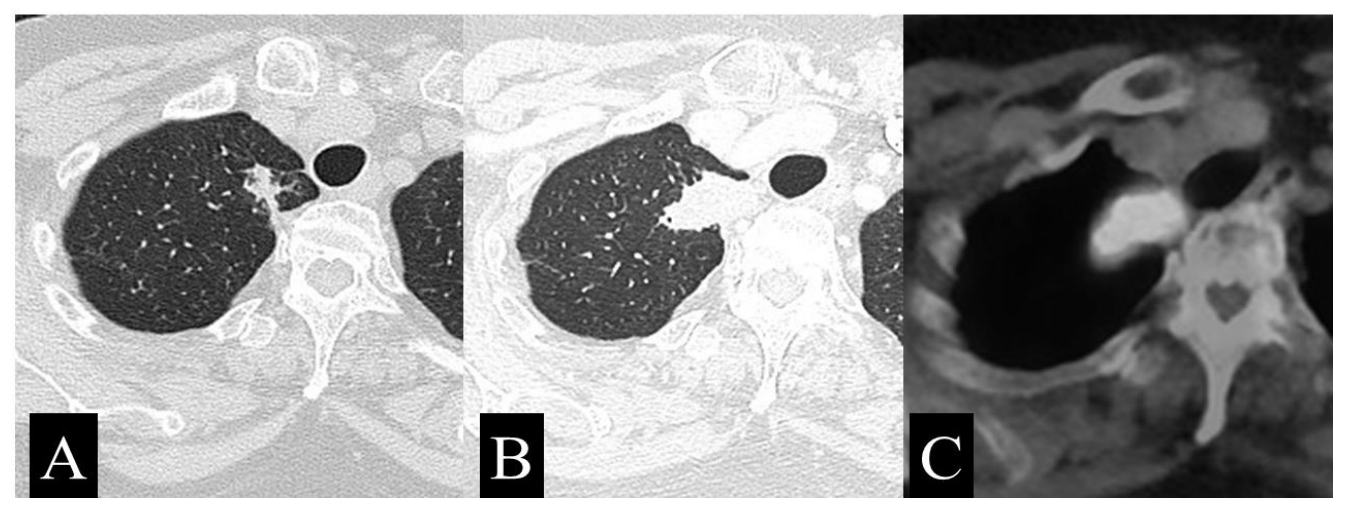

Figure 2. Chest CT and FDG-PET/CT of lung NTM nodule in a patient (Patient number 6 in Table 1). A: a maximum diameter $16.18 \mathrm{~mm}$ nodule in the upper right lobe taken on the first chest CT scan, B: the same nodule increased up to $32.79 \mathrm{~mm}$ taken at prior to surgical biopsy, C: FDG-PET/CT scan showing the SUV max of the nodule was 20. 


\section{DISCUSSION}

To the best of our knowledge, there has been no report on investigating VDT in lung NTM nodules. Therefore, this was the first study on this evaluation. Schwartz formula is a method of calculating VDT assuming that the nodule is spherical or has a shape similar to a spherical shape. The advantage of this method is that it is cheap and easy to calculate. Although nodule cannot be assumed to be spherical, VDT can be difficult to interpret, the median VDT in our eight patients with lung NTM nodules was 203 (range: 20-568) days. VDT was 100 days or less in 2 patients (No. 3 and 4), who's two CT scan interval of 50 days or less. On the other hand, VDT was the longest in patient No. 5 whose two CT scan interval close to 1,000 days. Due to the variability among nodules, VDT of them could not be exactly determined from the results of this study because of number of patients. Regarding VDT using chest $\mathrm{CT}$, there have been some reports in lung cancer patients [16-18]. The median VDT of lung cancer using CT have been reported to be 227-348 days in lung adenocarcinoma and 88-131 days in lung squamous cell carcinoma [16-18]. VDT of lung cancer was not examined in this study, so comparison in VDT of lung NTM nodules and that of lung cancer cannot be possible. However, it was suggested that VDT of lung NTM nodules was not so different from those with these two histopathological types of lung cancer. Judging from the results of this study, therefore, it may be difficult to distinguish between lung NTM nodules and lung cancer using VDT alone.

In patients with lung NTM, centrilobular, peribronchovascular multiple small nodules, bronchiectasis, consolidation, tree-in-bud in the middle lobe and/or lingual lobe are commonly observed findings in chest CT scan. In 7 of our 8 patients, such findings were observed in the same lobe as NTM nodule existed and in middle/lingular lobes. In fact, there have been a few case reports of lung cancer coexisting with lung NTM [9-13]. Taking these condition into consideration, at present, both information on lung field in the same or other lobes than lung NTM nodules exist must be comprehensively evaluated. In addition to information on lung field conditions other than these nodules, another interesting result of this study was that noticeable changes in the shape of the nodules were confirmed over time in 3 of 8 patients. Usually, in lung cancer, they often remain spherical growth unless special mechanical conditions are added, but this was not the case in these 3 patients. It was unclear whether this observation was useful for differentiating from lung cancer, but it was considered to be a noteworthy finding.

In this study, FDG-PET was performed in 6 of 8 patients. In FDG-PET, it has been reported that the SUVmax value of lung NTM nodules is not necessarily low [5, 14, 15]. Kawate et al. reported two lung NTM nodules with the SUVmax values 4.8 and 13.2, respectively [14]. In a lung NTM nodule reported by Min et al., the SUVmax value was 12.5 [15]. The average SUVmax value of 4 NTM nodules in a report by Hong et al was 4.9 (range: 3.6-7.8) [5]. FDG-PET in our 6 patients showed the median value 7.0, which was consistent with the results of these previous studies [5, 14, 15]. The SUVmax for lung cancer has been reported to be 10 or higher $[20,21]$. Budak et al. reported that it was 16.8 for lung adenocarcinoma and 17.9 for squamous cell lung cancer [20]. Al-Sarraf et al. reported that it was 15 for squamous cell lung cancer [21]. On the other hand, there have been many reports that SUVmax was less than 10 [22-24]. Usuda et al. report that it was 7.5 for malignant nodules and 3.9 for benign nodules [22]. Chrysikos et al. recommended a cutoff value of 5.0, and Zhou et al. reported a cutoff value of 3.9 [23, 24]. Based on these results, CT/PET-CT characteristics of lung nodules are not reliable in differentiating lung NTM nodules from malignant ones.

The limitations of this study were the small number of patients, the inconsistent CT imaging intervals, and the inclusion of patients with short imaging intervals. In fact, lung NTM nodules in this study evaluated were small nodules, and nodules with a low probability of obtaining appropriate samples by bronchoscopy or percutaneous biopsy. Therefore, CT imaging was performed at intervals according to the watch and wait policy. We thoroughly examined the indications for surgical biopsy. It is desirable to develop methods other than surgical biopsy that can obtain sufficient biopsy materials.

\section{CONCLUSION}

This was the first study to investigate VDT of nodule due to NTM. To avoid unnecessary resection, it may be better to collect various information on imaging findings in the nodule itself and in opacities other than the nodule. 
Introducere. Micobacterioza nontuberculoasă (NTM) a plămânului se poate dezvolta sub formă de noduli. Am examinat timpul de dublare al volumului (VDT) și valoarea SUVmax (maximum standardized uptake value) la analiza PET.

Metode. Au fost investigați retrospectiv 8 pacienți internați in perioada noiembrie 2012 - august 2018. Aceștia au fost urmăriți până în noiembrie 2020 și nu au dezvoltat cancer pulmonar sau reapariția nodulilor NTM. VDT a fost estimat folosind formula Schwartz.

Rezultate. Diametrul median al nodulului la momentul primei evaluări radiologice a fost de $16,0 \mathrm{~mm}(9,9-20,0 \mathrm{~mm})$. Diametrul median al nodulului înainte de biospia chirurgicală a fost de $18.8 \mathrm{~mm}(10,4-32,8 \mathrm{~mm})$. Timpul median de dublare estimat a fost de 203 zile (20-568 zile). La biopsie au fost identificați bacil acid alcoolo-rezistenți și granuloame cazeoase la toți cei 8 pacienți. La 5 pacienți s-a evidențiat Mycobacterium intracellulare și la 3 pacienți s-a evidențiat Mycobacterium avium. 6 pacienți au avut analiza PET CT și SUVmax median a fost de 7,0 (3,3-21,0). VDT median a fost de 200 zile.

Concluzii. Caracteristicile PET-CT/CT ale nodulilor pulmonari nu diferențiază între nodulii NTM și cei maligni. Pentru a evita rezecțiile inutile este mai bine a prelua cât mai multe informații asupra caracteristicilor imagistice.

Correspondence: Hiroaki Satoh, MD, PhD, Division of Respiratory Medicine, Mito Medical Center, University of Tsukuba-Mito Kyodo General Hospital, Miya-machi 3-2-7, Mito-city, Ibaraki, 310-0015, Japan, tel: +81-29-231-2371,

fax: +81-29-221-5137

E-mail: hirosato@md.tsukuba.ac.jp

Conflict of interest disclosure: The authors declare that there are not conflicts of interest.

Financial Support: None declared.

Authors' contributions: KN and HS designed the study. KN, KI, OI, YS, GO, KK and HS collected the data. KN, KK and HS analyzed the data and prepared the manuscript. All authors approved the final version of the article.

\section{REFERENCES}

1. LYNCH DA, SIMONE PM, FOX MA, BURCHER BL, HEINIG MJ. CT features of pulmonary Mycobacterium avium complex infection. J Comput Assist Tomogr. 1995; 19(3): 353-60.

2. MOORE EH. Atypical mycobacterial infection in the lung: CT appearance. Radiology. 1993; 187(3): 777-82.

3. TANAKA E, AMITANI R, NIIMI A, SUZUKI K, MURAYAMA T, KUZE F. Yield of CT and bronchoscopy for the diagnosis of Mycobacterium avium complex pulmonary disease. Am J Respir Crit Care Med. 1997; 155(6): 2041-6.

4. OBAYASHI Y, FUJITA J, SUEMITSU I, KAMEI T, NII M, TAKAHARA J. Successive follow-up of chest computed tomography in patients with Mycobacterium avium-intracellulare complex. Respir Med. 1999; 93(1): 11-15.

5. HONG SJ, KIM TJ, LEE JH, PARK JS. Nontuberculous mycobacterial pulmonary disease mimicking lung cancer: Clinicoradiologic features and diagnostic implications. Medicine (Baltimore). 2016; 95(26): e3978.

6. NAVID S, ARZHANG S, MIRZAEI A, KEFAYAT A, NADERI Z. Misleading of the diagnosis of Mycobacterium attributed lung diseases to malignancy due to smear, culture and PCR negative results: A lesson from a case report. Indian J Tuberc. 2020; 67(3): 371-3.

7. FOGLA S, PANSARE VM, CAMERO LG, SYEDA U, PATIL N, CHAUDHURY A. Cavitary lung lesion suspicious for malignancy reveals Mycobacterium xenopi. Respir Med Case Rep. 2018 Jan 3; 23: 83-5.

8. MEIER E, PENNINGTON K, GALLO DE MORAES A, ESCALANTE P. Characteristics of Mycobacterium avium complex (MAC) pulmonary disease in previously treated lung cancer patients. Respir Med Case Rep. 2017 Jun 23; 22: 70-3.

9. TEH RW, FEENEY K, FRANCIS RJ, PHILLIPS M, MILLWARD MJ. Mycobacterium mimicking metastatic melanoma. Intern Med J. 2013; 43(12): 1342-6.

10. BAE K, JUNG H, JEON KN, HYUN SD, KIM SH, KIM HC. Coexistence of nontuberculous mycobacterium and IgG4-related disease in a solitary pulmonary nodule: A case report. Medicine (Baltimore). 2019; 98(48): e18179.

11. GARG N, PUNCH C, STEIN M, SCHOFIELD C. When occam's razor can fail- active mycobacteria infection and lung cancer: A case of neuroendocrine lung cancer diagnosed in the setting of refractory mycobacterium avium-intracellulare. Clin Case Rep. 2018; 6(11): 2156-9.

12. MATSUMOTO A, ENOMOTO T, MUROYA Y, SUGISAKI M, SHINGU A, SAITOH H, et al. Pulmonary non-tuberculous mycobacteriosis (Mycobacterium intracellulare) with cavities developing in a non-small cell lung cancer patient during chemotherapy. Nihon Kokyuki Gakkai Zasshi. 2010; 48(8): 609-13.

13. NAKAMURA Y, OKADA Y, ENDO C, AIKAWA H, SAKURADA A, SATO M, et al. Endobronchial carcinoid tumor combined with pulmonary non-tuberculous mycobacterial infection: report of two cases. Lung Cancer. 2003; 39(2): $227-9$. 
14. KAWATE E, YAMAZAKI M, KOHNO T, FUJIMORI S, TAKAHASHI H. Two cases with solitary pulmonary nodule due to non-tuberculous mycobacterial infection showing intense $18 \mathrm{~F}$-fluorodeoxyglucose uptake on positron emission tomography scan. Geriatr Gerontol Int. 2010; 10(3): 251-4.

15. MIN Z, AMLANI M. Pulmonary Mycobacterium kansasii Infection Mimicking Malignancy on the (18) F-FDG PET Scan in a Patient Receiving Etanercept: A Case Report and Literature Review. Case Rep Pulmonol. 2014; 2014: 973573.

16. LINDELL RM, HARTMAN TE, SWENSEN SJ, JETT JR, MIDTHUN DE, TAZELAAR HD, et al. Five-year lung cancer screening experience: CT appearance, growthrate, location, and histologic features of 61 lung cancers. Radiology. 2007; 242(2): 555-62.

17. HONDA O, JOHKOH T, SEKIGUCHI J, TOMIYAMA N, MIHARA N, SUMIKAWA H, et al. Doubling time of lung cancer determined using three-dimensional volumetric software: comparison of squamous cell carcinoma and adenocarcinoma. Lung Cancer. 2009; 66(2): 211-7.

18. ODA S, AWAI K, MURAO K, OZAWA A, UTSUNOMIYA D, YANAGA Y, et al. Volume-doubling time of pulmonary nodules with ground glass opacity at multidetector CT: assessment with computer-aided three-dimensional volumetry. Acad Radiol. 2011; 18(1): 63-9.

19. SCHWARTZ M. A biomathematical approach to clinical tumor growth. Cancer. 1961; 14: 1272-94.

20. BUDAK E, ÇOK G, AKGUN A. The Contribution of Fluorine (18)F-FDG PET/CT to Lung Cancer Diagnosis, Staging and Treatment Planning. Mol Imaging Radionucl Ther. 2018; 27(2): 73-80.

21. AL-SARRAF N, GATELY K, LUCEY J, AZIZ R, DODDAKULA K, WILSON L, et al. Clinical implication and prognostic significance of standardised uptake value of primary non-small cell lung cancer on positron emission tomography: analysis of 176 cases. Eur J Cardiothorac Surg. 2008; 34(4): 892-7.

22. USUDA K, SAGAWA M, MOTONO N, UEDA M, TANAKA M, MACHIDA Y, et al. Diagnostic performance of diffusion weighted imaging of malignant and benign pulmonary nodules and masses: comparison with positron emission tomography. Asian Pac J Cancer Prev. 2014; 15(11): 4629-35.

23. CHRYSIKOS S, GKIOZOS I, DIMAKOU K, ZERVAS E, KAARAMPITSAKOS T, ANYFANTI M, et al. Clinical utility of thoracic endosonography (EBUS/EUS-b) in mediastinal staging of patients with non-small cell lung cancer: comparison with integrated PET/CT-a real-life prospective study in Greece. J Thorac Dis. 2020; 12(10): 5657-66.

24. ZHOU LM, YUAN LL, GAO Y, LIU XS, DAI Q, YANG JW, et al. Nucleophosmin 1 overexpression correlates with (18)F-FDG PET/CT metabolic parameters and improves diagnostic accuracy in patients with lung adenocarcinoma. Eur J Nucl Med Mol Imaging. 2020 Aug 27. doi: 10.1007/s00259-020-05005-4.

Received $11^{\text {th }}$ February 2021 